\title{
山口県阿武地域における白亜紀流紋岩類と花崗岩類の全岩化学組成および $\mathrm{Sr}, \mathrm{Nd}$ 同位体比
}

Whole-rock chemistry and $\mathrm{Sr}$ and Nd isotope ratios of Cretaceous rhyolites and granitoids in $\mathrm{Abu}$ district, Yamaguchi Prefecture, Southwest Japan

\section{弓削智子* 今岡照喜** \\ 飯泉 滋***}

\section{Tomoko Yuge*, Teruyoshi Imaoka** and Shigeru Iizumi***}

1997 年 6 月 2 日受付.

1997 年 11 月 25 日受理.

* 山口大学理学部地質学鉱物科学教室.

Department of Geology and Mineralogical Sciences, Faculty of Science, Yamaguchi University, Yamaguchi 753-8512, Japan 現在，株式会社日本パブリック関西支社.

Kansai Branch, Nihon Public Co., Ltd. Higashiyodogawa-ku, Osaka 533-0033, Japan

** 山口大学理学部地球科学教室.

Department of Earth Sciences, Faculty of Science, Yamaguchi University, Yamaguchi 753-8512, Japan

*** 島根大学総合理工学部地球資源環境学教室. Department of Geoscience, Faculty of Science and Engineering, Shimane University, Matsue 690-8504, Japan

\section{Abstract}

Cretaceous felsic volcanic and granitic rocks, which are widely distributed in the Chugoku district, SW Japan, frequently constitute typical volcano-plutonic complexes. The Fukuga Formation of the Abu Group in the northeastern part of Yamaguchi Prefecture unconformably overlies the Cretaceous Kanmon and Shunan Groups. The Fukuga Formation, which is mainly composed of rhyolite to rhyodacite lavas and pyroclastic rocks, is intruded by a granitic stock, suggesting that the volcanic and granitic rocks comprise a volcano-plutonic complex. We have examined the genetic relationship between the volcanic and granitic rocks using major and trace element chemistry and $\mathrm{Sr}$ and $\mathrm{Nd}$ isotope ratios.

The rhyolites and granites have similar major and trace element chemistry except for Ba, which is lower in the granitic rocks and decreases markedly in concentration from biotite granite to aplite. $\mathrm{Ba}$ vs. $\mathrm{Sr}$ relations indicate $\mathrm{K}$-feldspar fractionation in the granitic magma chamber. Ten rhyolite samples of the Fukuga Formation and eight granite samples yield similar, well-defined $\mathrm{Rb}-\mathrm{Sr}$ whole rock isochrons. The Fukuga suite gives an isochron of $86.8 \pm 2.8 \mathrm{Ma}(2 \sigma)$ with an initial $\mathrm{Sr}$ isotope ratio of $0.70544 \pm 0.00024$, and the granites give an isochron of $85.0 \pm 3.1 \mathrm{Ma}(2 \sigma)$ with an initial ratio of 0.70526 \pm 0.00023 . All rhyolites and granites give a single combined isochron of $87.0 \pm 3.1 \mathrm{Ma}(2 \sigma)$ with the initial ratio of $0.70526 \pm$ 0.00025 . While plagioclase, K-feldspar, whole rock samples from a biotite granite give an isochron age of $79.7 \pm 5.3 \mathrm{Ma}(2 \sigma)$ with an initial ratio of $0.70521 \pm 0.00017$. The petrographical, petrochemical and $\mathrm{Sr}$ and $\mathrm{Nd}$ isotope data indicate that the rhyolite of the Fukuga Formation and the granitic rocks were derived from a common source, which were slightly enriched source (probably lower crust), contrasting with other Cretaceous volcanic rocks in the Chugoku district.

Key words: granite, rhyolite, $\mathrm{Rb}-\mathrm{Sr}$ isochron age, $\mathrm{Nd}$ isotope, Cretaceous, SW Japan
序論

火山一深成複合岩体は，火山岩とそれを供給したマグマ溜 まりの化石と考えられるプルトンの両者が地表に露出する程 度の削剝レベルに達したものであり，「火山の根」あるいは 「火山の下部構造」(荒牧・横山，1979）とみることができる. 活動を終えた火山とプルトンの両者を地表で観察できる 火山一深成複合岩体の岩石学的研究からは，マグマ溜まりの 中でのプロセスや進化を解明する上で，第四紀の火山からは 容易に得られない長時間にわたる重要な情報を引き出せる可
能性が高い. 火山岩はマグマ溜まりの早期の情報を凍結して いるであろうし, 深成岩は分別結晶作用などマグマの冷却過 程を凍結しているであろう。これらを総合すれば，マグマ留 まりの進化についての情報を引き出せる可能性がある (高橋, 1990). 中国地方には白亜紀の流紋岩類（匹見層群や 阿武層群相当層) とその地下での固結体である花崗岩類（広 島花咸岩) が広く分布しており（第 1 図）, これらはいくつか のステージの火山-深成作用によって形成されたものとして 理解されている (Murakami, 1974 ; 村上・今岡, 1986). それ ら火成岩類の岩石学的ならびに同位体的研究からは上述の問 


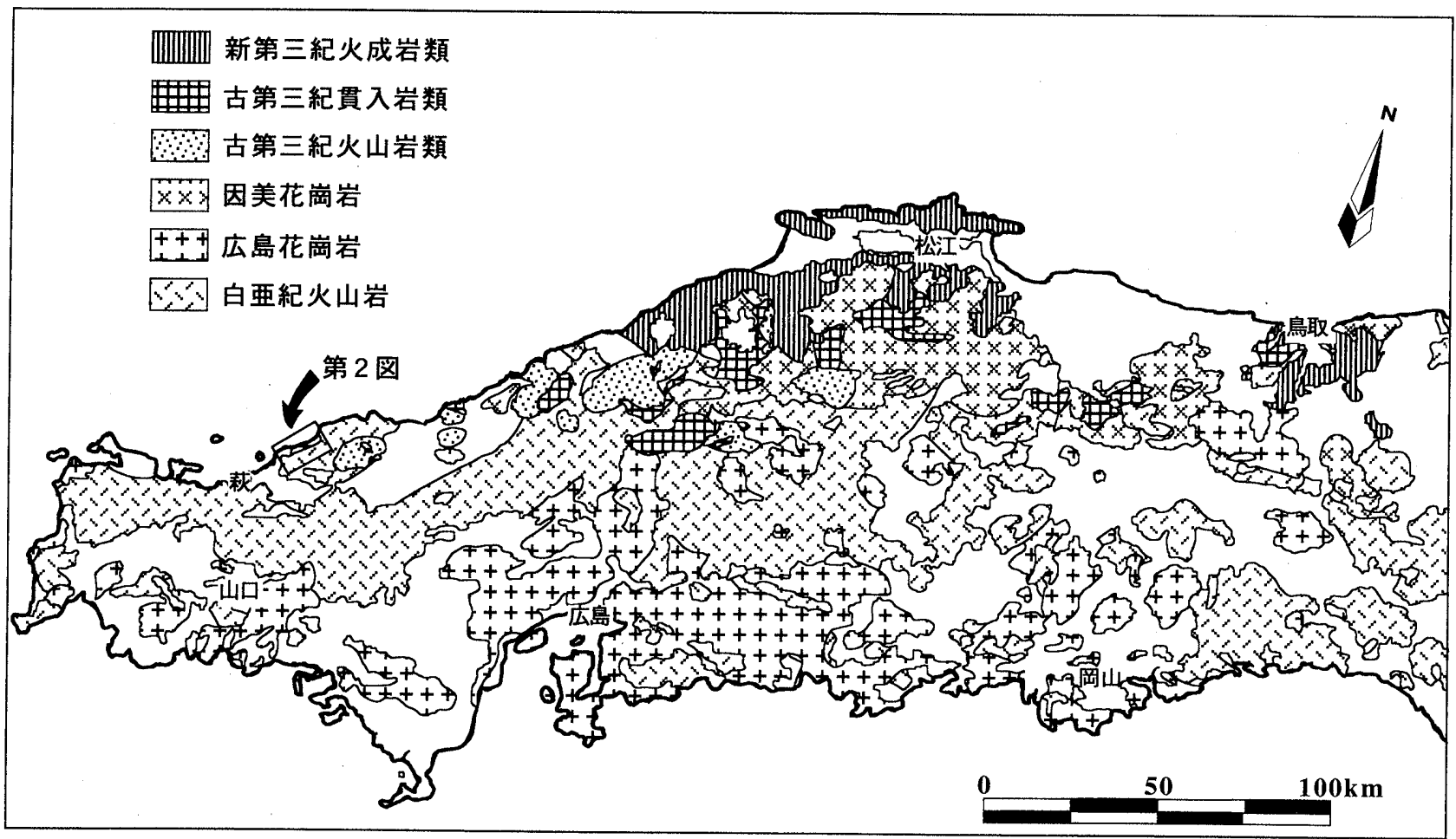

第 1 図. 中国地方に扔ける白亜紀〜第三紀火成岩類の分布図（地質調查所，1992 簡略化）.

題解明のための情報が得られるすのと期待されるが，両者の 成因的関係は必ずしも明らかではない。

白亜紀阿武層群は，主として乾陸上に噴出した火砕岩から 構成されるために年代測定に有効な試料が得られにくいこと や時代特定に有効な化石の産出がそしいことああって，時代 が十分に特定されていない，表題地域（第 1 図）の阿武層群 は比較的多量の溶岩を含むこと, 詳細な火山層序学的研究が 行われていること, 関連すると考えられる花崗岩を随伴して いることから，本研究においては，表題地域の阿武層群の流 紋岩溶岩および花崗岩類を研究対象とし, この地域の火山樑成作用を明らかにすることを目的として全岩の主成分およ び微量元素成分， $\mathrm{Sr}, \mathrm{Nd}$ 同位体比について検討した。

\section{地質と岩石の概要}

西中国地域の白覀紀火山岩層は，下位加ら関門層群，周南 層群，匹見層群抢よび阿武層群に層序区分される（村上・ 今岡, 1986).このうち阿武層群は中国地方西部の脊梁山地加 ら山陰にかけて分布し，広大な分布域を有している．本層群 を構成する岩石は, 乾陸上に堆積した流紋岩質〜流紋デイサ イト質溶結凝灰岩抢よび溶岩を主とし，凝死質仯岩や頁岩な どの湖水堆積層を伴う（今岡ほか, 1984 ; 村上・今岡, 1986). 本層群は山口県北西部地域では下位の青海累層と上 位の熊野岳累層に, 県中央部では下位から篠目累層, 舞谷累 層および江舟累層に, 標題地域の屯のは福賀累層として層序 区分されている（村上・今岡, 1986 ; 西村ほか, 1995).

阿武地域（第 1 図）の地質については村上（1968）の編集 による 5 万分の 1 須佐図幅が公表され，その後神谷 (1974b)
によって層序・構造が再検討され, その詳細が報告されてい る.ここではその概略について記述する。この地域の地質は 主として自亜紀の関門層群, 周南層群および阿武層群福賀累 層とこれらに貫入する花崗岩類によって構成されている（第 2 図). 関門層群は脇野亜層群の黒色頁岩層, 下関亜層群の変 質安山岩類と礫岩 - 砂岩 - 赤色頁岩の互層からなり, この地 域の西部に分布する．これを不整合に覆う周南層群田床山火 山岩類は流紋岩類を主としている，福賀累層はこれらを不整 合で覆い, 本地域では下位から金井安山岩層, 木与谷層およ び三ヶ岳流紋岩層に区分され, 全層厚は $1,800 \sim 2,000 \mathrm{~m}$ 之 推定される．金井安山岩層は輝石安山岩溶岩打よび同質凝灰 岩を主とし，デイサイト質凝灰岩を伴う。最大層厚は約 300 $\mathrm{m}$ である. 木与谷層は下部では流紋岩質凝灰岩が優勢である のに対し, 上部では凝灰質砂岩・シルト岩・頁岩などの陸水 堆積物が優勢である. 本層の最大層厚は約 $400 \mathrm{~m}$ である. 三 ケ岳流紋岩層は流紋岩溶岩, 同質凝灰岩および溶結凝灰岩か らなり, 最大層厚は約 $1,100 \mathrm{~m}$ に達する. その大半は流紋岩 質溶結凝灰岩で占められる。溶結凝灰岩中の本質レンズにつ いて 67.2士2.2 Ma（本稿では，K-Ar 年代はすべて Steiger and Jäger, 1977 による新しい壊变定数で再計算した值を記 す）の全岩 $\mathrm{K}-\mathrm{Ar}$ 年代が報告されている（柴田・神谷, 1974).

花崗岩類は日本海の海岸線に沿って露出するほか, 野島と 姫島にむ分布する (第 2 図). 主として黒雲母花崗岩からな り,アプライトを伴う. 神谷 (1974b) によれば黒雲母花崗岩 は阿武層群福賀累層の下底に水平な板状形態を有して貫入 し，それらに対して著しい接触変成作用を与えている. 

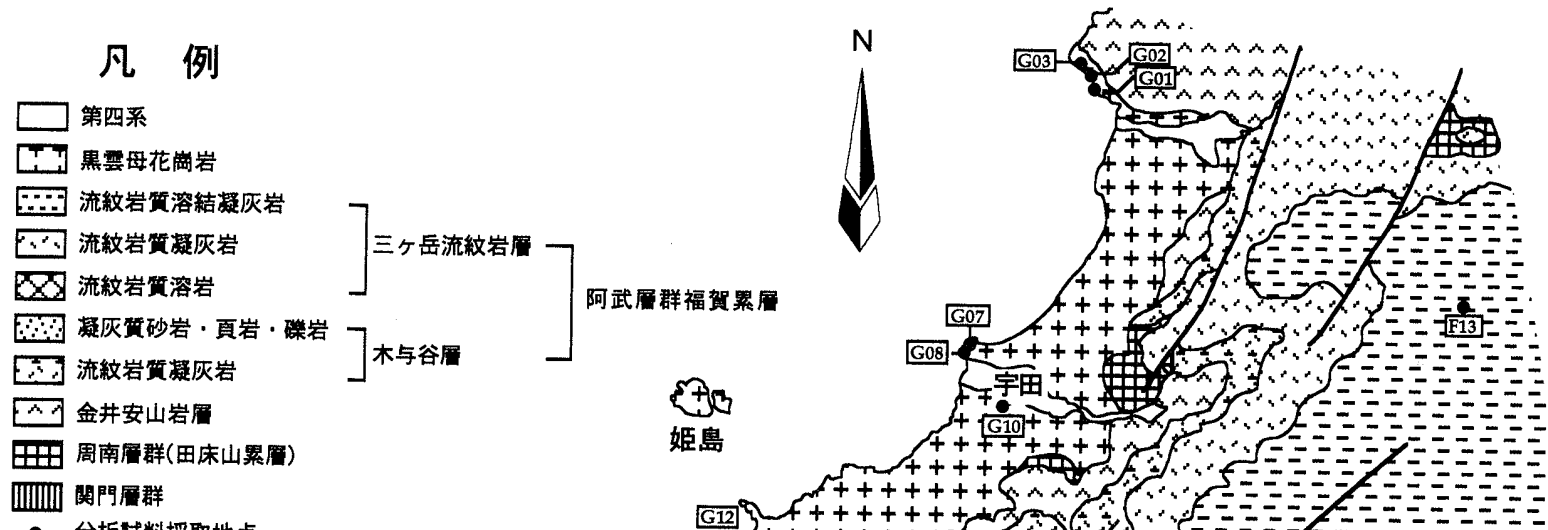

- 分析試料採取地点

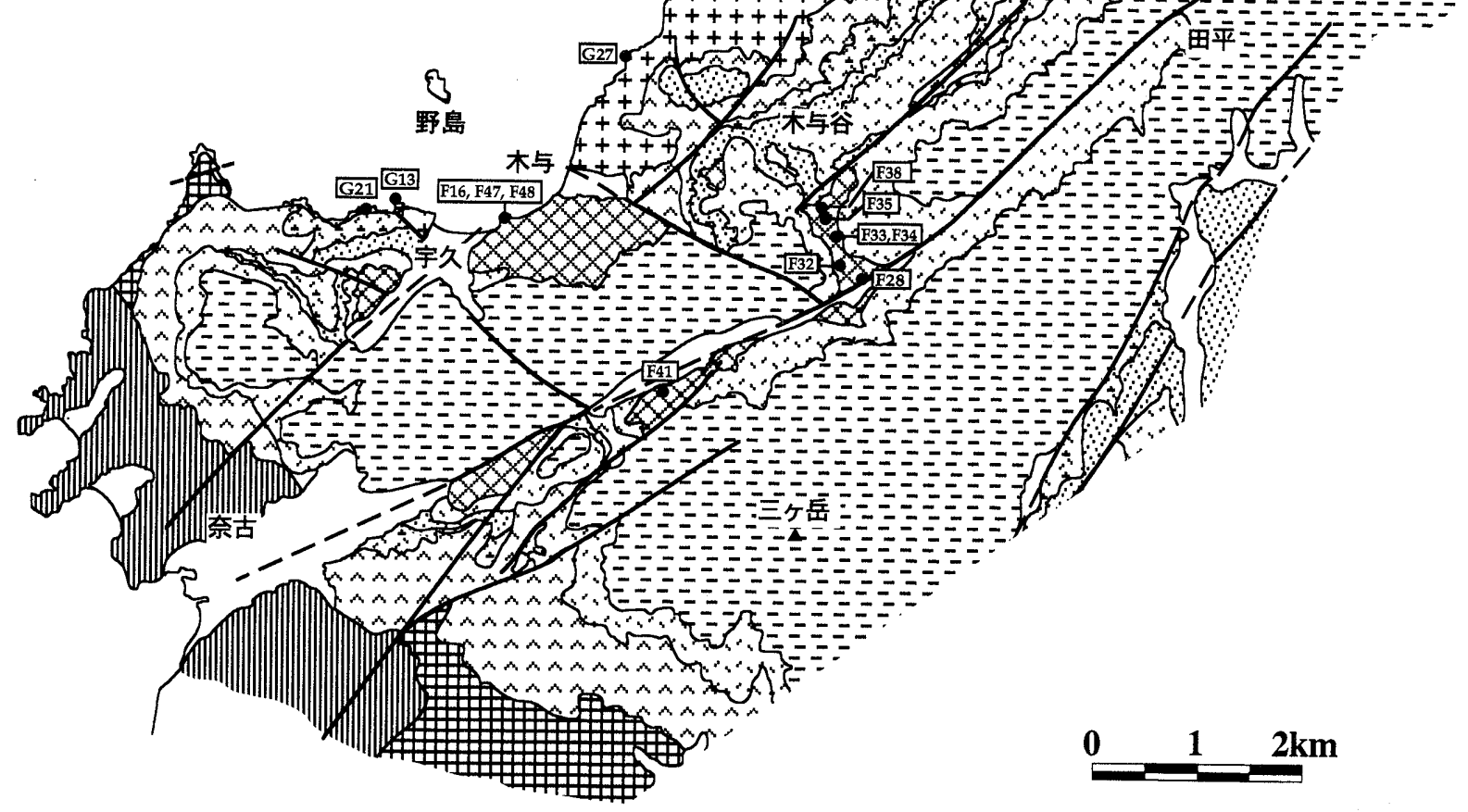

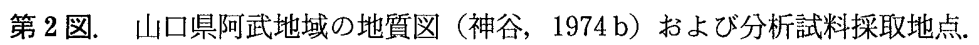

Kamitani (1977) は黒雲母花崗岩は火山活動後あまり時間間 隙のない時期に貫入したものであろう，と記述している，花 崗岩については，93 Ma の黒雲母 $\mathrm{K}-\mathrm{Ar}$ 年代（河野・植田, 1966）と $91 \mathrm{Ma}$ の Rb-Sr黒雲母-全岩アイソクロン年代 （Seki，1978）が報告されている。带磁率は $50 \times 10^{-6} \mathrm{emu} / \mathrm{g}$ 以下の低い值を示し，イルメナイト系列に属する（Imaoka and Nakashima, 1983). 黒雲母花崗岩は肉眼および鏡下観 察の結果から中粒相, 細粒相および斑状相に細分できるが, それらは漸移的に变化し, 相互に貫入関係は認められない。 細粒花崗岩は一般に岩体の周縁相を形成する。また，岩体の 周縁部では白雲母が増加し，黒雲母が減少すると同時に，小 規模ながら多数の白雲母-カリ長石一石英のペグマタイトが認 められる．この地域には熱水変質帯が広範囲に分布し，その 一部がろう石鉱床としての経済性を有し，古くからその研究 が行われてきた（岩生，1950; 神谷，1974 a). 熱水変質帯の 白雲母 $\mathrm{K}-\mathrm{Ar}$ 年代として, $84.3 \pm 2.7 \mathrm{Ma}$ と $83.8 \pm 2.6 \mathrm{Ma}$ （柴田・神谷, 1974）が報告されている.

\section{全岩化学組成}

\section{1. 分析試料}

阿武層群福賀累層三ヶ岳流紋岩層中の代表的な流紋岩溶岩 および花崗岩類（黒雲母花崗岩, アプライト) について全岩 の主成分および微量元素成分の化学分析を行った. 分析試料 の採取地点を第 2 図に示す. 約 $0.5 \sim 2 \mathrm{~kg}$ の試料をタングス テンカーバイト乳鉢で粗砕し, その一部を四分法で取り分 け,メノウのボールミルで約 10 ミクロン以下に粉砕した。

流紋岩溶岩は主に阿武町木与から木与谷にかけて分布する ものを採取した。本岩は淡灰色〜淡緑色を呈し, 肉眼で顕著 な流理構造が観察される. 鏡下では斑晶として石英, 斜長石, 黒雲母, 不透明鉱物とごく少量のカリ長石, 希に角閃石が見 られる、一般に斜長石は自形を呈する. 石英は著しく融食さ れているが，ごくまれに自形の石英を観察できる．石基は隠 微晶質〜微晶質組織を示し, しばしば球顆構造が観察され る. 流紋岩溶岩はこの地域の金井安山岩層や木与谷層の岩石 


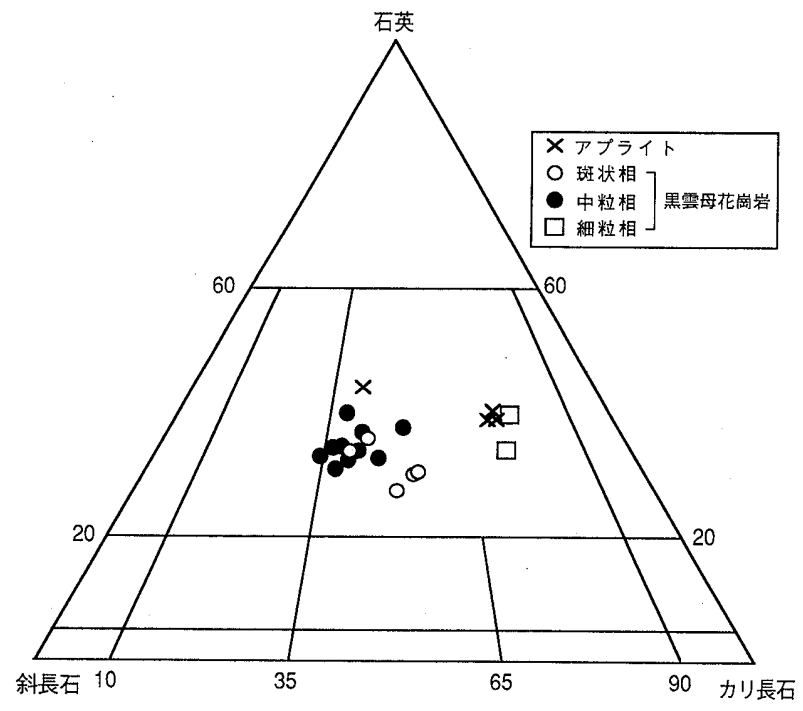

第 3 図. 花崗岩類の石英-カリ長石-斜長石容量比.

に比較して新鮮である（神谷, $1974 \mathrm{~b}$ ).

花崗岩類としたものは黒雲母花崗岩とアプライトに大別さ れる. 黒雲母花崗岩は肉眼および鏡下観察の結果から中粒の あの (中粒相), 細粒のもの (細粒相), カリ長石の斑状組織 の顕著なむの（斑状相）に細分できるが，組織変化は連続的 である. 本岩の主な構成鉱物は斜長石, 石英, カリ長石, 黒 雲母で, 白雲母を含むことがあるが, 角閃石は認められない. また，副成分鉱物としてはジルコン，アラナイト，不透明鉱 物が含まれる，斜長石はアルバイト式双晶をなし，また斑状 相においてはパッチゾーニングが特徴的に観察される。ま た, 斜長石のコアは若干セリサイト化している. 石英は一般 に他形を示し, カリ長石と微文象構造を呈している。 カリ長 石にはパーサイト構造が見られる. 斑状相のカリ長石は大き い屯のでは長径が約 $2 \mathrm{~cm}$ に達する. 黑雲母は緑泥石化が著 しいものもある．化学分析した花崗岩類のモード組成を第 3 図を示す。命名はIUGS Subcommission（1973）に従った. 本地域の黒雲母花崗岩の主岩相である中粒相や斑状相は花崗 岩の領域の中であ花崗閃緑岩側にプロットされ, 細粒相やア プライトはやや石英に富む. 斑状相は中粒相に比較し, やや カリ長石に富む.

\section{2. 分析方法}

分析は山口大学機器分析センターに設置の理学電機製全自 動蛍光 X 線分析装置 (RIX 3000) を用いて行った. 測定方法 は角縁ほか（1989）に従った. 主成分元素の分析は岩石 1 に 対し、メルク社製四ほう酸リチウム5 (重量比) で作成した ガラスビードで行った. 微量元素成分 ( V, Cr, Ni, Cu, Zn, $\mathrm{Ga}, \mathrm{Rb}, \mathrm{Sr}, \mathrm{Ba}, \mathrm{Y}, \mathrm{Zr}, \mathrm{Nb})$ の分析は, 岩石 1 に対して メルク社製四ほう酸リチウム 1 (重量比)を混合し，さらにポ リビニルアルコールを混ぜてプレスして固めた粉末ペレット で行った. $\mathrm{FeO}$ は, 過マンガン酸カリウム滴定法によって定 量した.

\section{3. 分析結果}

主成分および微量元素成分の分析結果を第 1 表および第
4, 5 図に示す.

グラフの横軸に D.I. (分化指数) をとった主成分の組成变 化を第 4 四に示す。縦軸の各元素は, 無水に換算している. 流紋岩溶岩の $\mathrm{SiO}_{2}$ は 74.1 80.4 wt.\%であり，それらのほ とんよ゙は $\mathrm{SiO}_{2}$ が $75 \mathrm{wt} \%$ 以上の高シリカ流紋岩組成を示し， D.I. は 83.3〜95.3である. また, 花崗岩類の $\mathrm{SiO}_{2}$ は 73.1〜 78.4 wt.\%, D.I. は84.6 94.7であり, 流紋岩溶岩のそれと 類似した值を示す. $\mathrm{TiO}_{2}, \mathrm{Al}_{2} \mathrm{O}_{3}, \mathrm{FeO}^{*}, \mathrm{MgO}, \mathrm{CaO}, \mathrm{P}_{2} \mathrm{O}_{5}$ は D.I. の増加ととむに減少する傾向がみられるが， $\mathrm{K}_{2} \mathrm{O}$ は D.I. の増加とと屯に増加する傾向にある，流紋岩溶岩す花崗 岩類もすべてノルムコランダムが算出される，ぼの元素につ いても流紋岩溶岩と花崗岩類の組成には明瞭な違いは認めに くい.

微量成分の組成变化を第 5 図に示す. Cr, Y には流紋岩溶 岩より屯花崗岩の方が若干高い值を示す傾向がみられる。た だし Cr はいずれあ $10 \mathrm{ppm}$ 以下の低い值である，花崗岩類， とくにアプライトの Ba は流紋岩溶岩に比較し，低い值を示 す. 全体的に V, Ga, Sr, Zr には右下がりのトレンドが, $\mathrm{Rb}$ には右上がりのトレンドがみられる. しかし，その他の成分 については流紋岩溶岩と花崗岩類の組成には明瞭な違いは認 めにくい.

$\mathrm{K}_{2} \mathrm{O}$ の増加と, $\mathrm{Al}_{2} \mathrm{O}_{3}, \mathrm{CaO}, \mathrm{Sr}$ の減少は斜長石の分別に よって, $\mathrm{TiO}_{2}, \mathrm{FeO}^{*}, \mathrm{MgO}, \mathrm{V}, \mathrm{Zn}$ の減少はイルメナイト をはじめとするマフィック鉱物の分別によって， $\mathrm{P}_{2} \mathrm{O}_{5}$ の減 少, Zr の減少はそれぞれアパタイト，ジルコンの分別で説明 され，これらは流紋岩溶岩と花崗岩類に共通に見られる現象 である。しかし，既述のようにBaについては花崗岩類が流 紋岩溶岩に比較し，低い值を示す。また，流紋岩溶岩は D.I. の増加とととに Ba の顕著な現象が見られないが，黒雲母花 崗岩からアプライトにかけて Ba は顕著に減少している.

第 6 図に $\mathrm{Ba}-\mathrm{Sr}$ および $\mathrm{Rb}-\mathrm{Sr}$ 図を示す。これらの図には 黒雲母・カリ長石・斜長石の分別トレンドを示した。分別卜 レンドは Hanson（1978）で示された分配係数を使用した. 花崗岩類は $\mathrm{Ba}$ が 100 900 ppm, Sr が 30 200 ppm, Rb が 100 200 ppm の間で変化している. 花崗岩類は $\mathrm{Ba}$ が増加 するにつれて $\mathrm{Sr}$ あ増加し， $\mathrm{Rb}$ が増加すると $\mathrm{Sr}$ が減少する 傾向がある. 第 5 図や第 3,4 図に示した組成变化図から流紋 岩溶岩や花崗岩類の組成変化はカリ長石と斜長石の分別結晶 作用, とくにカリ長石の分別によって説明されると考えられ る. 結局, 微量元素の挙動に見られる花崗岩類之流紋岩溶岩 の間の違いを生じさせた主要な鉱物はカリ長石であろう。

\section{Sr および Nd 同位体比}

\section{1. 測定試料}

阿武層群福賀累層のうち，流紋岩溶岩の産出する三ヶ岳流 紋岩層の流紋岩溶岩 8 試料, 花崗岩類を代表する全岩 8 試料 と鉱物 2 試料を同位体分析に用いた。試料の採取地点を第 2 図に示す．流紋岩溶岩の試料は模式地の木与海岸をはじめと して，地質図上で散在する流紋岩溶岩分布域からむれなく採 取した. 分析した岩石の化学組成を第 1 表に示す。

花崗岩類は既述のように黒雲母花崗岩（中粒相・細粒相・ 


\begin{tabular}{|c|c|c|c|c|}
\hline 0 & 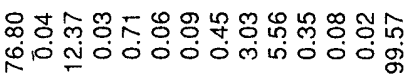 & 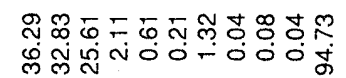 & 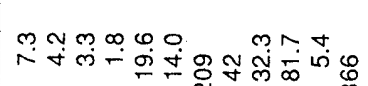 & 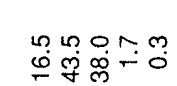 \\
\hline 总 & 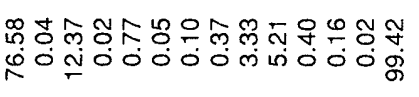 & 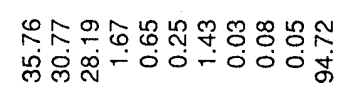 & 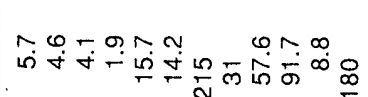 & 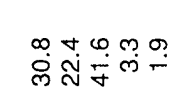 \\
\hline : & 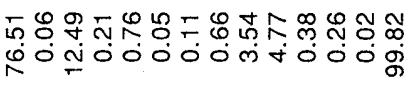 & 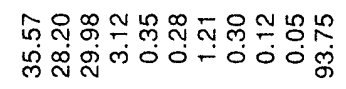 & 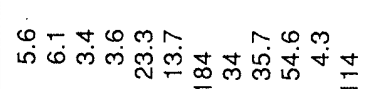 & 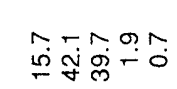 \\
\hline$\frac{\pi}{N}$ & 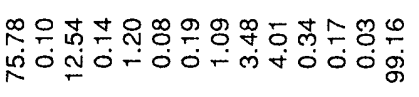 & 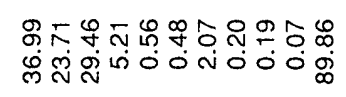 & ஸैơ & 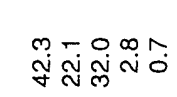 \\
\hline$\overline{\mathbb{N}}$ & 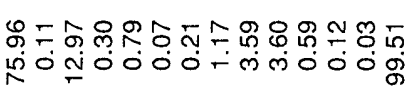 & 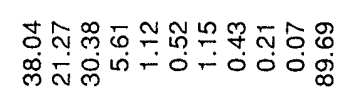 & 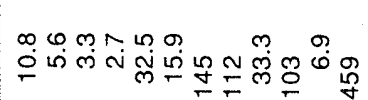 & त̛̃ \\
\hline ֶ̃ & 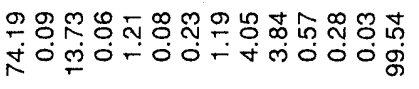 & 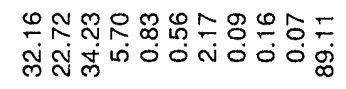 & 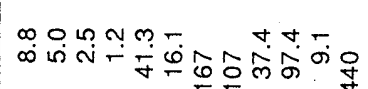 & 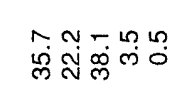 \\
\hline$\frac{0}{10}$ & 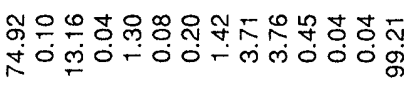 & 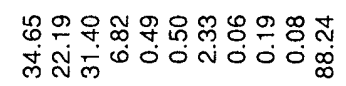 & कें & 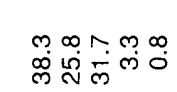 \\
\hline 总 & 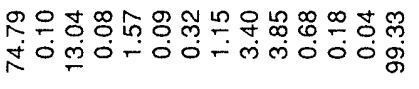 & 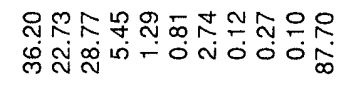 & 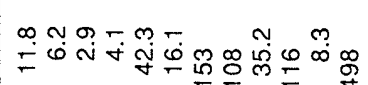 & 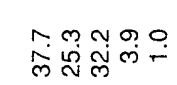 \\
\hline$\frac{m}{i n}$ & 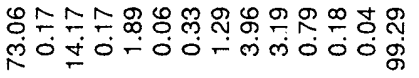 & 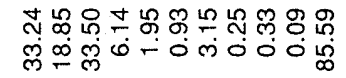 & 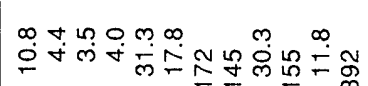 & 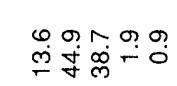 \\
\hline$\sqrt{\nwarrow}$ & 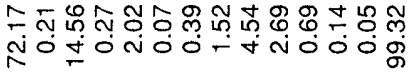 & 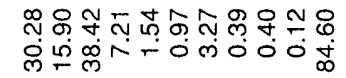 & 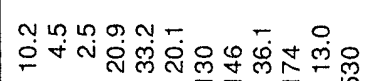 & 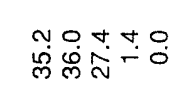 \\
\hline$\stackrel{0}{4}$ & 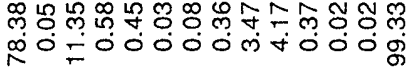 & 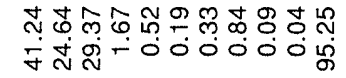 & 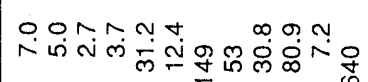 & \\
\hline$\stackrel{\infty}{+}$ & 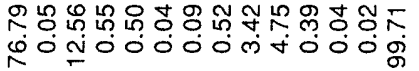 & 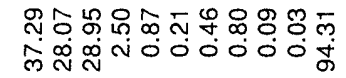 & $\begin{array}{l}\infty \\
\infty \\
\infty \\
\infty\end{array}$ & \\
\hline f & 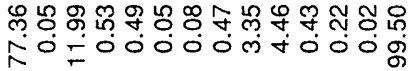 & 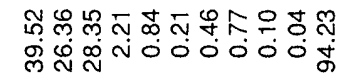 & 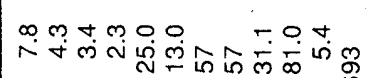 & \\
\hline 开 & 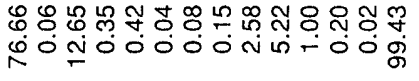 & 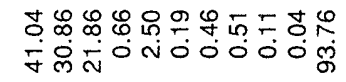 & 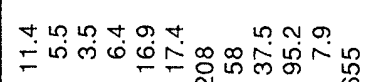 & \\
\hline 芭 & 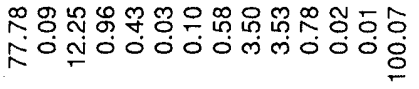 & 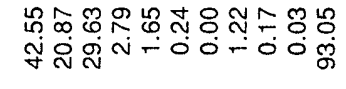 & 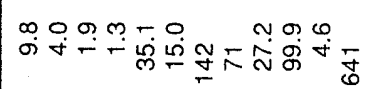 & \\
\hline- & 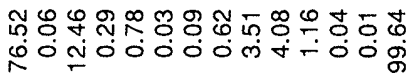 & $\begin{array}{l}0 \\
0 \\
\infty \\
\infty \\
\infty\end{array}$ & 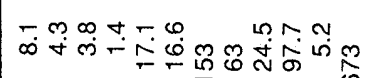 & \\
\hline$\stackrel{\sim}{\sim}$ & 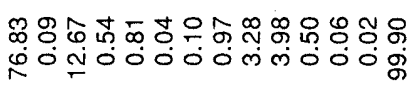 & 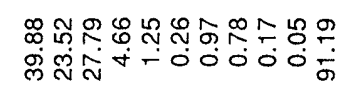 & 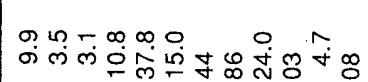 & \\
\hline 芯 & 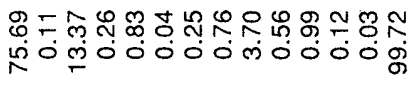 & 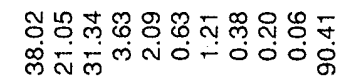 & 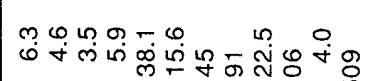 & \\
\hline ల్ల & 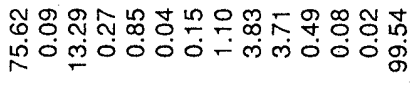 & 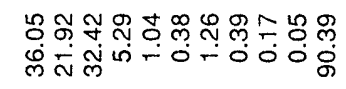 & 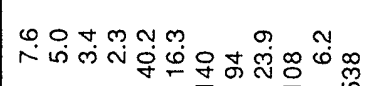 & \\
\hline ల్ల్ల్ల & 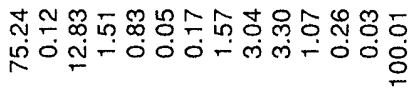 & 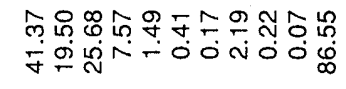 & 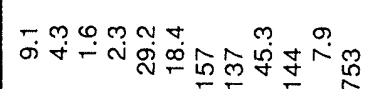 & \\
\hline ల్లుㄴ & 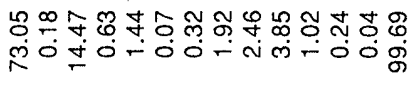 & 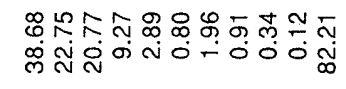 & 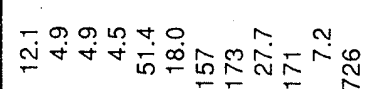 & \\
\hline i & 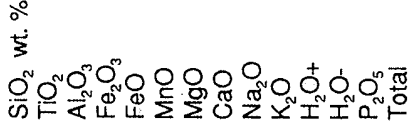 & 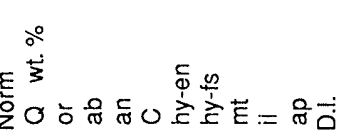 & 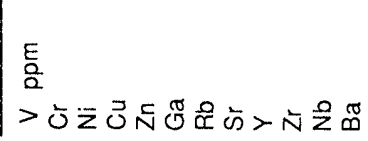 & 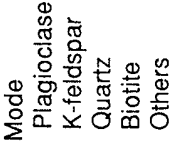 \\
\hline
\end{tabular}



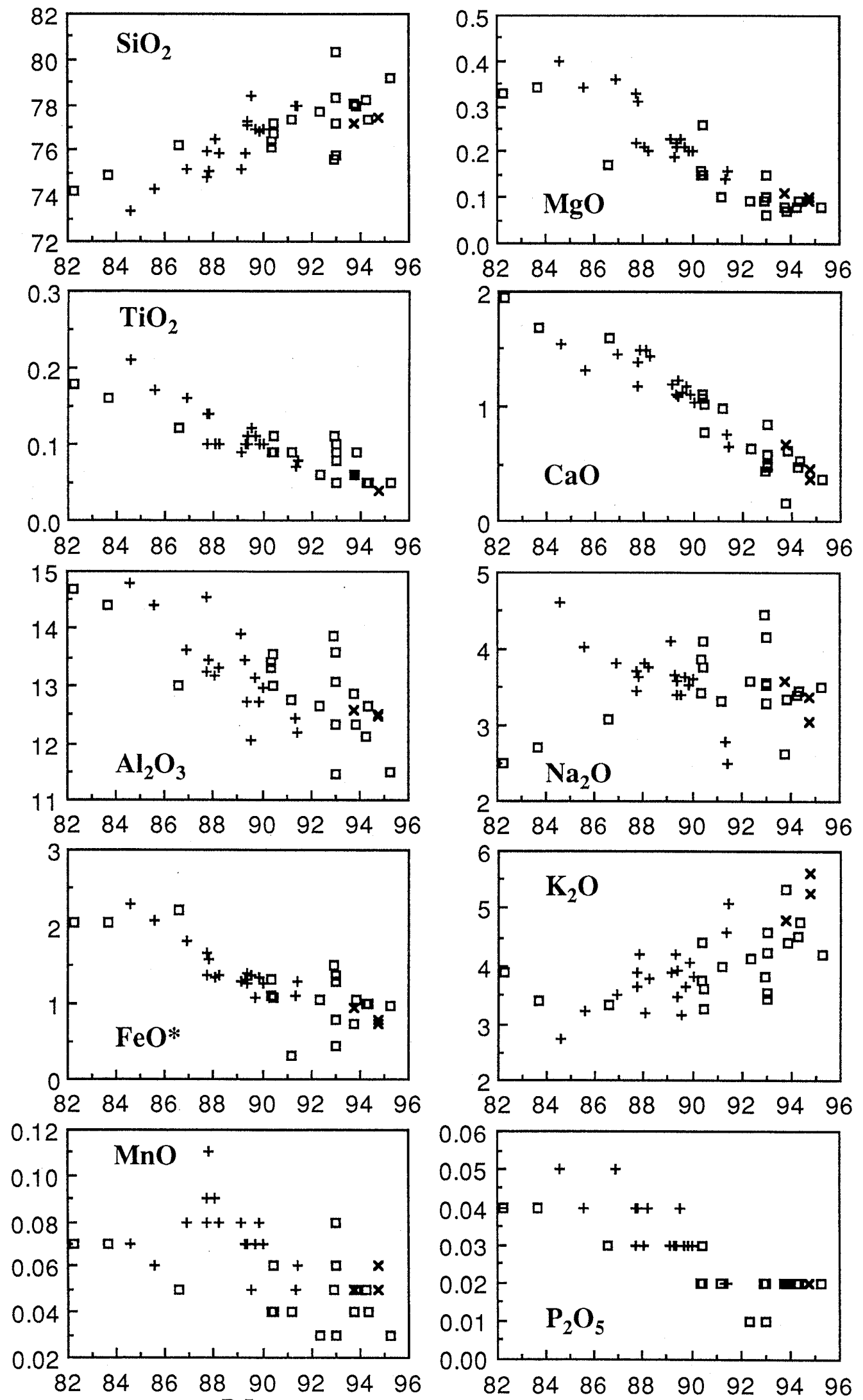

D.I.

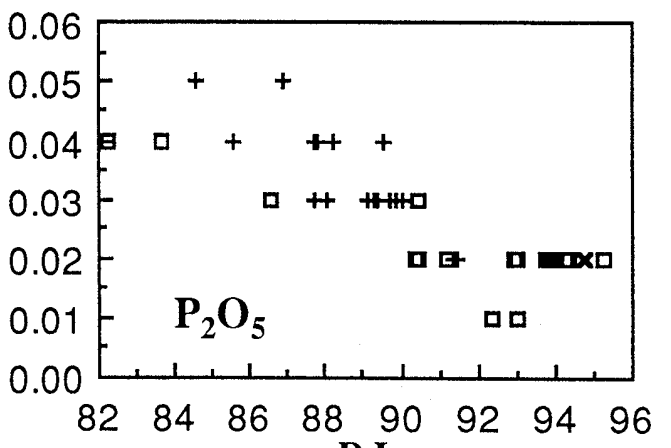

口 流紋岩溶岩 + 黒雲母花崗岩 $\times$ アプライト

第 4 図. 阿武層群 流紋岩溶岩および 花崗岩類の主成分 变化図. 

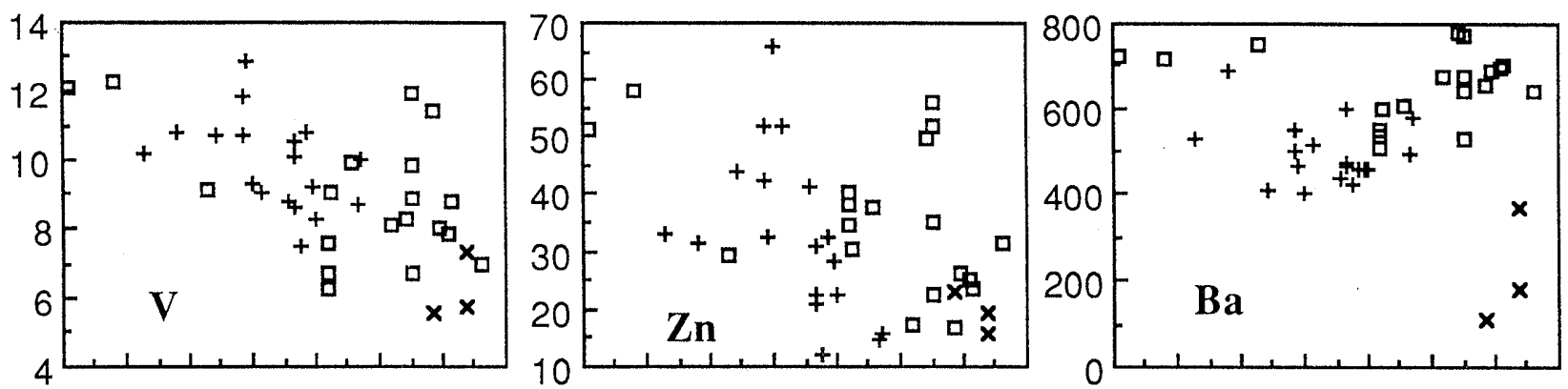

$\begin{array}{llllllllllllllll}82 & 84 & 86 & 88 & 90 & 92 & 94 & 96 & 82 & 84 & 86 & 88 & 90 & 92 & 94 & 96\end{array}$
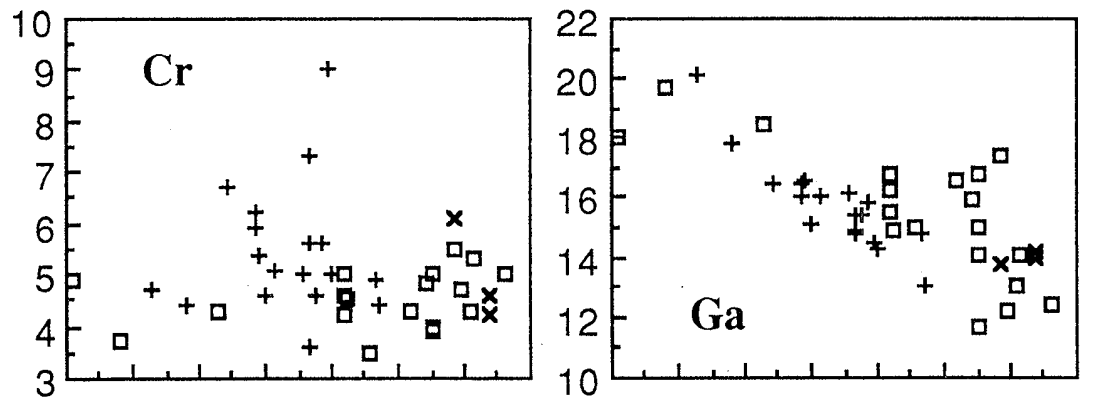

$\begin{array}{llllllll}82 & 84 & 86 & 88 & 90 & 92 & 94 & 96\end{array}$

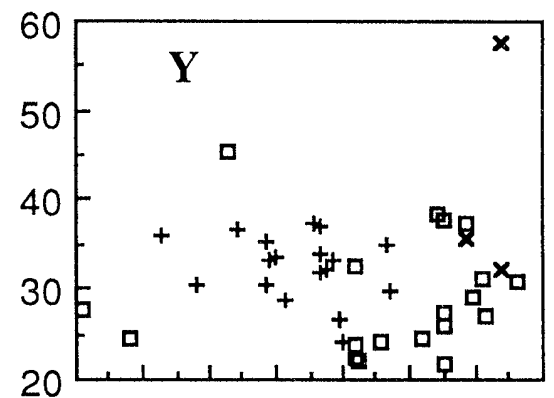

$\begin{array}{llllllll}82 & 84 & 86 & 88 & 90 & 92 & 94 & 96\end{array}$
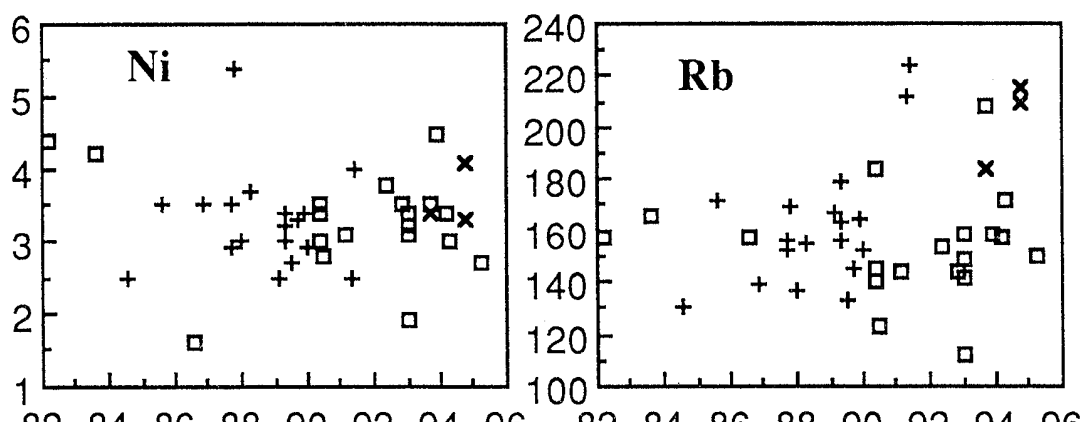

$\begin{array}{llllllll}82 & 84 & 86 & 88 & 90 & 92 & 94 & 96\end{array}$

$\begin{array}{llllllllllllllll}82 & 84 & 86 & 88 & 90 & 92 & 94 & 96 & 82 & 84 & 86 & 88 & 90 & 92 & 94 & 96\end{array}$
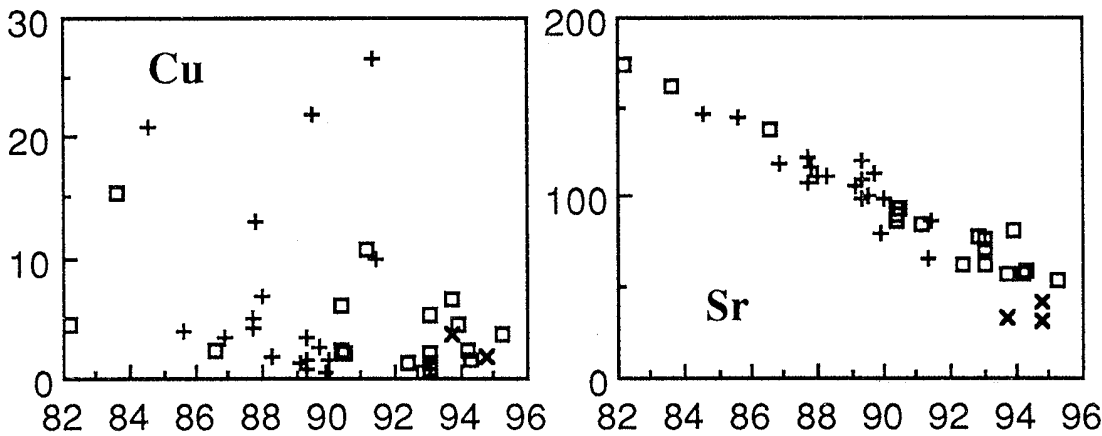

D.I.

D.I.

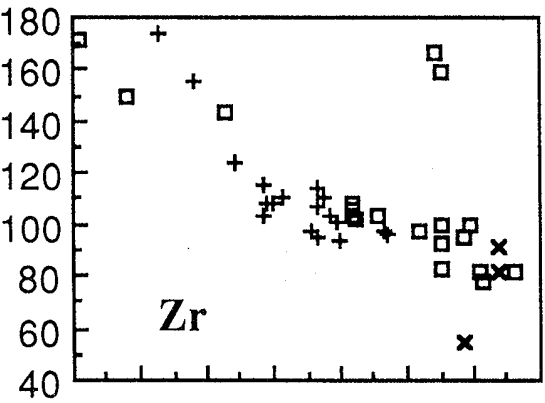

$\begin{array}{llllllll}82 & 84 & 86 & 88 & 90 & 92 & 94 & 96\end{array}$

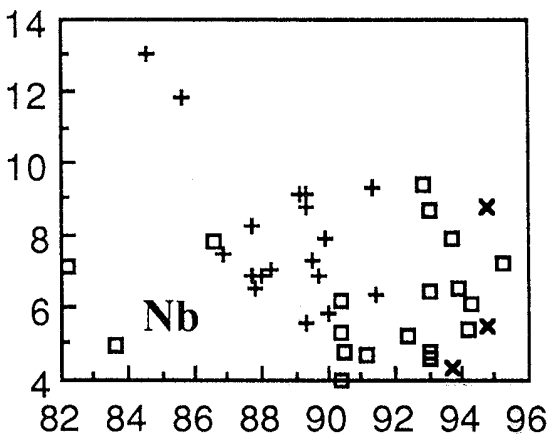

D.I.

第 5 図. 阿武層群流紋岩溶岩および花崗岩類の微量成分变化図. 凡例は第 4 図と同じ.

斑状相）とアプライトに区分されるが，それぞれの代表的な 試料を分析に供した，分析した岩石のモード組成および化学 組成を第 1 表に示す.このうち G07については, 斜長石と力 リ長石を分離した. 分離方法は, 岩石を旋回粉砕機で粉砕後, 粉末のサイズを標準フルイで 80-150メッシュに整え，洗 浄・乾燥した。そして磁鉄鉱などの強磁性鉱物を磁石で取り 除き, 電磁分離と重液（クレリチ重液）分離を繰り返し，精 選した。

\section{2. 測定方法}

流紋岩質溶岩を代表する全岩 10 試料, 花崗岩類を代表す る全岩 8 試料と鉱物 2 試料について $\mathrm{Sr}, \mathrm{Nd}$ 同位体比の測定 を行った， $\mathrm{Sr}, \mathrm{Nd}$ 同位体比，鉱物の $\mathrm{Sr}, \mathrm{Rb}$ 濃度, 全岩の $\mathrm{Nd}, \quad \mathrm{Sm}$ 濃度の測定は，島根大学総合理工学部の MAT 262 型質量分析計を使用し, 測定方法は飯泉（1996）に従った。 この方法による Sr や Nd 同位体用の標準試料 (NBS 987, La 

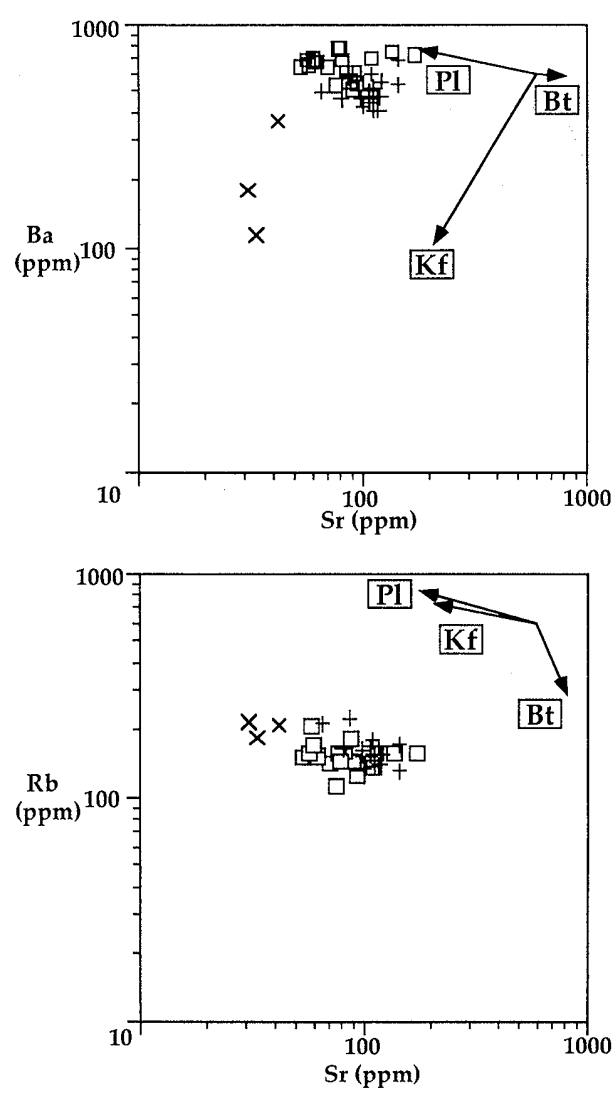

第 6 図. 阿武層群流紋岩溶岩および花岡岩類の $\mathrm{Ba}-\mathrm{Sr}$, $\mathrm{Rb}-\mathrm{Sr}$ 変化図. 凡例は第 4 図之同じ.

Jolla）や地質調查所（GSJ）の標準試料についての測定結果 については Iizumi et al. (1994，1995) に報告されている. アイソクロンはYork (1966) の方法で求めた. $\varepsilon \mathrm{Sr}, \varepsilon \mathrm{Nd}$ 初 生値を求めるのに用いた CHUR (Chondritic Uniform Reservoir) のパラメーターは次のとおりである. ${ }^{87} \mathrm{Sr} /{ }^{86} \mathrm{Sr}$ (present $)=0.7045,{ }^{87} \mathrm{Rb} /{ }^{86} \mathrm{Sr}$ (present) $=0.0827, \quad \lambda^{87} \mathrm{Rb}=1.42$ $\times 10^{-11} \mathrm{y}^{-1},{ }^{143} \mathrm{Nd} /{ }^{144} \mathrm{Nd}$ (present) $=0.512638,{ }^{147} \mathrm{Sm} /{ }^{144} \mathrm{Nd}$ (present) $=0.1966, \quad \lambda^{147} \mathrm{Sm}=6.54 \times 10^{-12} \mathrm{y}^{-1}$. 第 2 表に示 す試料の测定期間中に Sr 同位体標準試料 NBS 987 および $\mathrm{Nd}$ 同位体標準試料 La Jolla の測定を併せて行った。 NBS 987 は期間中 3 回測定し，それらの ${ }^{87} \mathrm{Sr} /{ }^{86} \mathrm{Sr}$ 值は, 0.710263

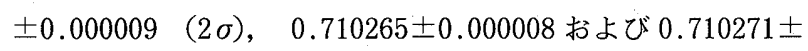
0.000009 であった。 また, La Jolla は 2 回測定し, これら $の^{143} \mathrm{Nd} /{ }^{144} \mathrm{Nd}$ 值は, $0.511851 \pm 0.000009(2 \sigma)$ おょび $0.511847 \pm 0.000009$ を示した. これらの值は, 多くの研究機 関から公表されているデー夕と一致していることから, 測定 されたデータについての標準試料による補正は行っていな w.

\section{3. 測定結果}

第 2 表に流紋岩溶岩，花崗岩類の $\mathrm{Rb}, \mathrm{Sr}, \mathrm{Nd}, \mathrm{Sm}$ 含有量, ${ }^{87} \mathrm{Rb} /{ }^{86} \mathrm{Sr}$ 比, ${ }^{143} \mathrm{Nd} /{ }^{144} \mathrm{Nd}$ 比の測定結果を示す.こ のデー夕をむとにアイソクロン法を用いて $\mathrm{Rb}-\mathrm{Sr}$ 年代を求 めた。

流紋岩溶岩の全岩アイソクロン図を第 7 図に示す。年代は

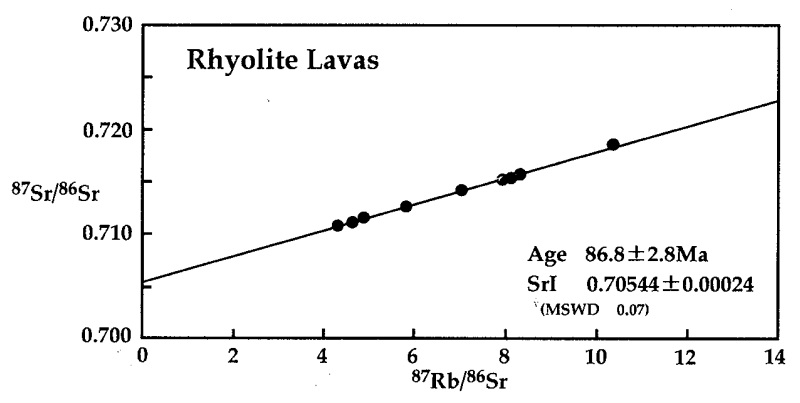

第 7 図. 阿武層群流紋岩溶岩の全岩アイソクロン図.

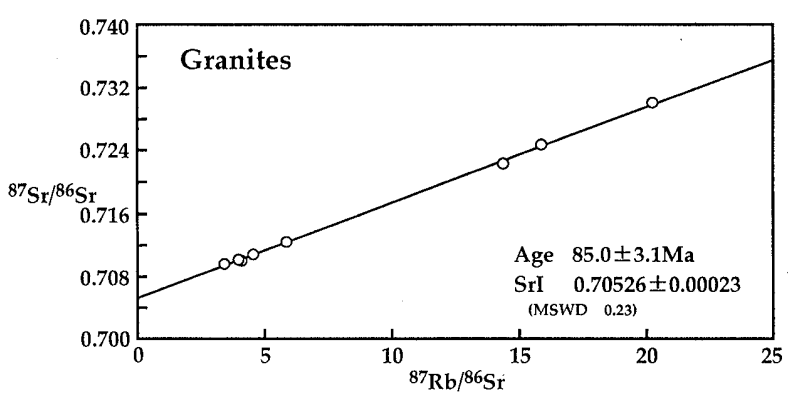

第 8 図. 花崗岩類の $\mathrm{Rb}-\mathrm{Sr}$ 全岩アイソクロン図.

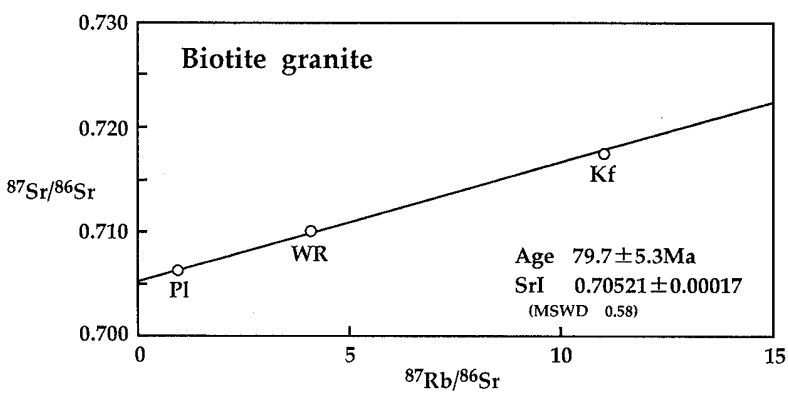

第 9 図. 黒雲母花崗岩の $\mathrm{Rb}-\mathrm{Sr}$ 全岩-鉱物アイ ソクロン図.

$86.8 \pm 2.8 \mathrm{Ma}, \mathrm{Sr}$ 同位体初生值（以下 $\mathrm{SrI}$ 值と示す）は

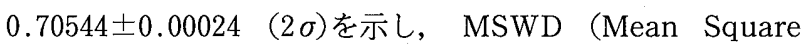
Weighted Deviation)は 0.07 と非常に低い值を示す。

花崗岩類の全岩アイソクロン図を第 8 図に示す. 年代は 85.0土3.1 Ma, SrI 值は $0.70526 \pm 0.00023(2 \sigma)$ が得られた. また, MSWDは 0.23 である。流紋岩溶岩とは誤差範囲で重 複する. 黒雲母花崗岩の全岩-斜長石一カリ長石アイソクロン 図を第 9 図に示す。年代は 79.7士5.3 Ma, SrI 值は 0.70521 $\pm 0.00017(2 \sigma)$ が得られた。 また, MSWDは0.58である. 年代の中央値は全岩アイソクロン年代と比較しやや若い年代 を示すが誤差範囲で一致する.

流紋岩溶岩と花崗岩類全サンプルで求めた全岩アイソクロ ンを第 10 図に示す。分析された岩石はすべて同一アイソク ロン上にのっている. 年代は87.0土3.1 Ma, SrI 值は $0.70526 \pm 0.00025(2 \sigma)$ であり, MSWD は 0.35 である.

$\varepsilon \mathrm{Nd}$ 初生值についてみると, 流紋岩溶岩は $0.1 \sim 0.6$, 花崗 岩類は $-0.2 \sim 0.6$ で, いずれも变化幅は小さく, 両者は類似 
第 2 表. 阿武層群福賀累層の流紋岩溶岩および花崗岩類の $\mathrm{Rb}, \mathrm{Sr}, \mathrm{Nd}, \mathrm{Sm}$ 含有量および $\mathrm{Sr}, \mathrm{Nd}$ 同位体比.

\begin{tabular}{|c|c|c|c|c|c|c|c|c|c|c|c|}
\hline No. & 岩石名 & $\begin{array}{l}\mathrm{Rb} \\
\mathrm{ppm}\end{array}$ & $\begin{array}{l}\mathrm{Sr} \\
\mathrm{ppm}\end{array}$ & ${ }^{87} \mathrm{Rb} /{ }^{86} \mathrm{Sr}$ & ${ }^{87} \mathrm{Sr} /{ }^{86} \mathrm{Sr}$ & $\begin{array}{l}\text { Initial } \varepsilon \mathrm{Sr} \\
\quad(85 \mathrm{Ma})\end{array}$ & $\begin{array}{l}\mathrm{Nd} \\
\mathrm{ppm}\end{array}$ & $\begin{array}{l}\text { Sm } \\
\mathrm{ppm}\end{array}$ & ${ }^{147} \mathrm{Sm} /{ }^{144} \mathrm{Nd}$ & ${ }^{143} \mathrm{Nd} /{ }^{144} \mathrm{~N}$ & $\begin{array}{c}\text { Initial } \varepsilon \mathrm{Nd} \\
\quad(85 \mathrm{Ma})\end{array}$ \\
\hline \multicolumn{12}{|c|}{ 阿武層群福賀累層 } \\
\hline $\mathrm{F} 32$ & 流紋岩質溶岩 & 140 & 94 & 4.30 & $0.710762(14)$ & 16.5 & 53.0 & 3.78 & 0.043 & $0.512567(17)$ & 0.3 \\
\hline F34 & 流紋岩質溶岩 & 145 & 91 & 4.62 & $0.711096(14)$ & 15.8 & 25.0 & 3.66 & 0.089 & $0.512581(09)$ & 0.1 \\
\hline F28 & 流紋岩質溶岩 & 144 & 86 & 4.86 & $0.711523(18)$ & 17.8 & & & & & \\
\hline F35 & 流紋岩質溶岩 & 142 & 71 & 5.82 & $0.712602(09)$ & 16.6 & 22.8 & 3.51 & 0.093 & $0.512606(08)$ & 0.5 \\
\hline F13 & 流紋岩質溶岩 & 153 & 63 & 7.03 & $0.714150(10)$ & 17.9 & & & & & \\
\hline F47 & 流紋岩質溶岩 & 157 & 57 & 7.93 & $0.715122(15)$ & 16.2 & 27.9 & 4.96 & 0.108 & $0.512619(08)$ & 0.6 \\
\hline $\mathrm{F} 16$ & 流紋岩質溶岩 & 149 & 53 & 8.13 & $0.715267(14)$ & 14.9 & 23.0 & 4.15 & 0.109 & $0.512609(14)$ & 0.4 \\
\hline F48 & 流紋岩質溶岩 & 172 & 60 & 8.33 & $0.715670(10)$ & 17.2 & & & & & \\
\hline \multicolumn{12}{|c|}{ 花崗岩類 } \\
\hline G13 & 細粒黑雲母花崗岩 & 172 & 145 & 3.43 & $0.709531(13)$ & 14.0 & 26.0 & 4.24 & 0.099 & $0.512581(09)$ & -0.1 \\
\hline G10 & 中粒黒雲母花崗岩 & 154 & 111 & 4.01 & $0.710117(10)$ & 12.4 & & & & & \\
\hline \multirow[t]{3}{*}{ G07 } & 斑状黑雲母花崗岩 & 153 & 108 & 4.11 & $0.709997(11)$ & 9.1 & 20.9 & 3.90 & 0.113 & $0.512594(13)$ & 0.1 \\
\hline & 斜長石 & 138 & 425 & 0.94 & $0.706264(09)$ & & & & & & \\
\hline & カリ長石 & 349 & 92 & 11.0 & $0.717401(10)$ & & & & & & \\
\hline G02 & 細粒黑雲母花崗岩 & 167 & 107 & 4.54 & $0.710798(09)$ & 13.0 & 20.6 & 3.91 & 0.115 & $0.512582(11)$ & -0.2 \\
\hline G12 & 斑状黑雲母花崗岩 & 164 & 81 & 5.89 & $0.712361(09)$ & 12.0 & 20.4 & 3.61 & 0.107 & $0.512618(12)$ & 0.6 \\
\hline G01 & アプライト & 209 & 42 & 14.4 & $0.722178(22)$ & 6.2 & 23.2 & 4.29 & 0.112 & $0.512607(09)$ & 0.3 \\
\hline G08 & アプライト & 184 & 34 & 15.9 & $0.724643(09)$ & 15.1 & & & & & \\
\hline G03 & アプライト & 215 & 31 & 20.3 & $0.730049(14)$ & 16.8 & & & & & \\
\hline
\end{tabular}

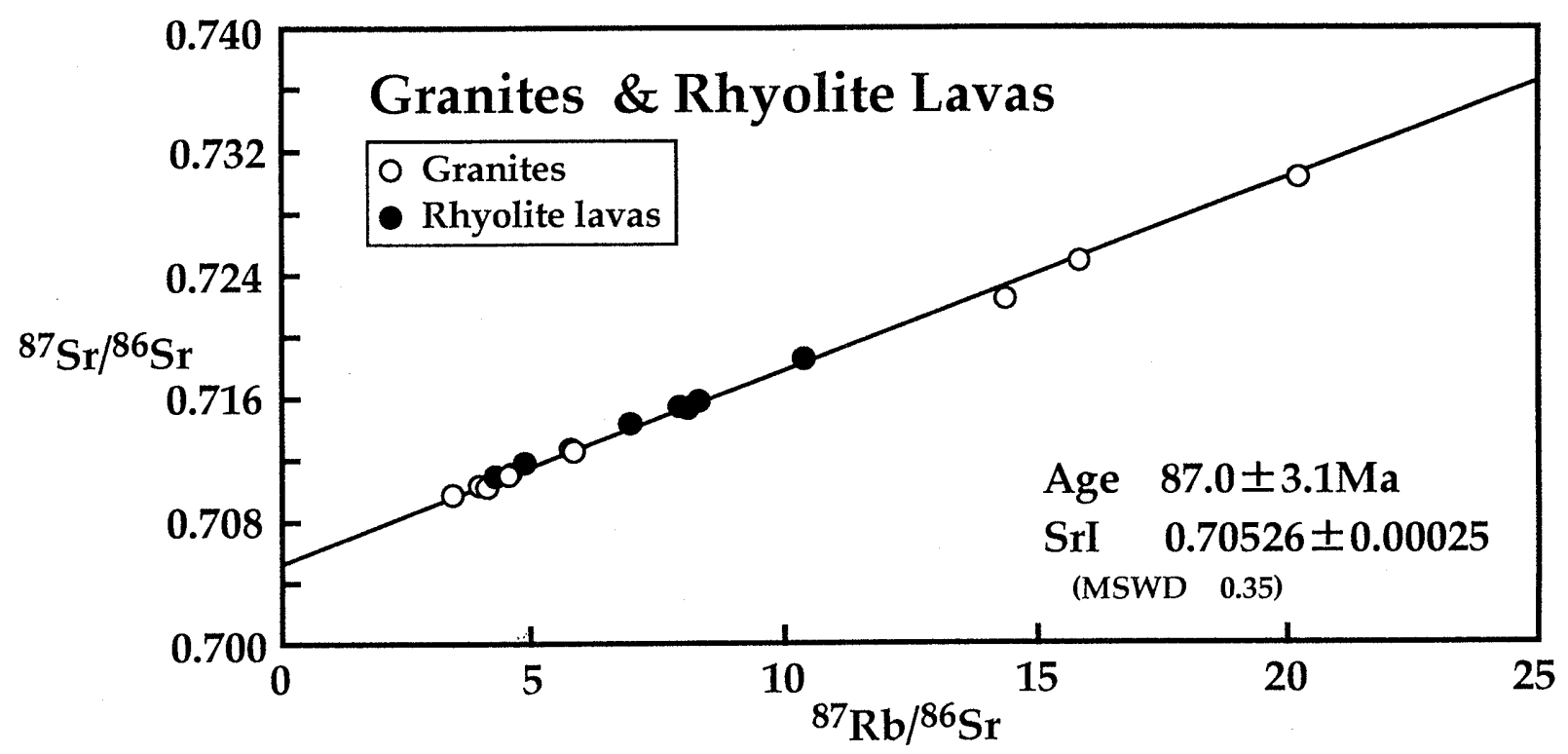

第 10 図. 花崗岩類および阿武層群流紋岩溶岩の $\mathrm{Rb}-\mathrm{Sr}$ 全岩アイソクロン図.

した值を示す (第 2 表).

\section{考察}

\section{1. 既報年代值との関係について}

中国・四国地方における白亜紀〜第三紀火成岩類の放射年 代については今岡ほか（1994）によって総括されている，こ のうち, 阿武層群についてみる之, 青海累層について $93.8 \pm$ $2.2 \mathrm{Ma}, 94.7 \pm 2.4 \mathrm{Ma}, 91.8 \pm 3.3 \mathrm{Ma}$ のジルコン FT 年代 （上田・西村，1982），熊野累層については 78.6士5.2 Ma の ジルコン FT 年代 (上田・西村, 1982) が報告されている. 篠

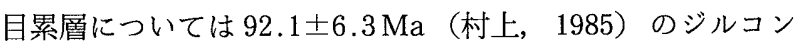
$\mathrm{FT}$ 年代, $112 \pm 4 \mathrm{Ma}$ の Rb-Sr 全岩年代 (Seki, 1978) が報告
されている，福賀累層については流紋岩溶結凝灰岩に対し $84.5 \pm 5.7 \mathrm{Ma}$ のジルコン FT 年代（村上, 1985), $84 \mathrm{Ma}$ と $84 \mathrm{Ma}$ の白雲母 $\mathrm{K}-\mathrm{Ar}$ 年代と $67 \mathrm{Ma}$ の全岩 $\mathrm{K}-\mathrm{Ar}$ 年代（柴 田・神谷, 1974), 87.1士2.6 Maのセリサイト $\mathrm{K}-\mathrm{Ar}$ 年代 (Kitagawa et al., 1988) がある.

これらの既報年代值のうち，FT 年代はいずれも灭砕岩中 のジルコンであり, Hurford (1990) の FT 年代測定法に関す る国際勧告以前に報告されたものである．また Seki (1978) の $112 \pm 4 \mathrm{Ma}$ は，西南日本の白亜紀火山岩類の $\mathrm{Rb}-\mathrm{Sr}$ 年代 測定を最初に試みた中でその一貫として報告されたものであ るが, 層序的に阿武層群の下位にある関門層群の安山岩やデ イサイト中の角閃石 $\mathrm{K}-\mathrm{Ar}$ 年代 $105.2 \pm 3.3 \mathrm{Ma}, 106.7 \pm 3.3$ 


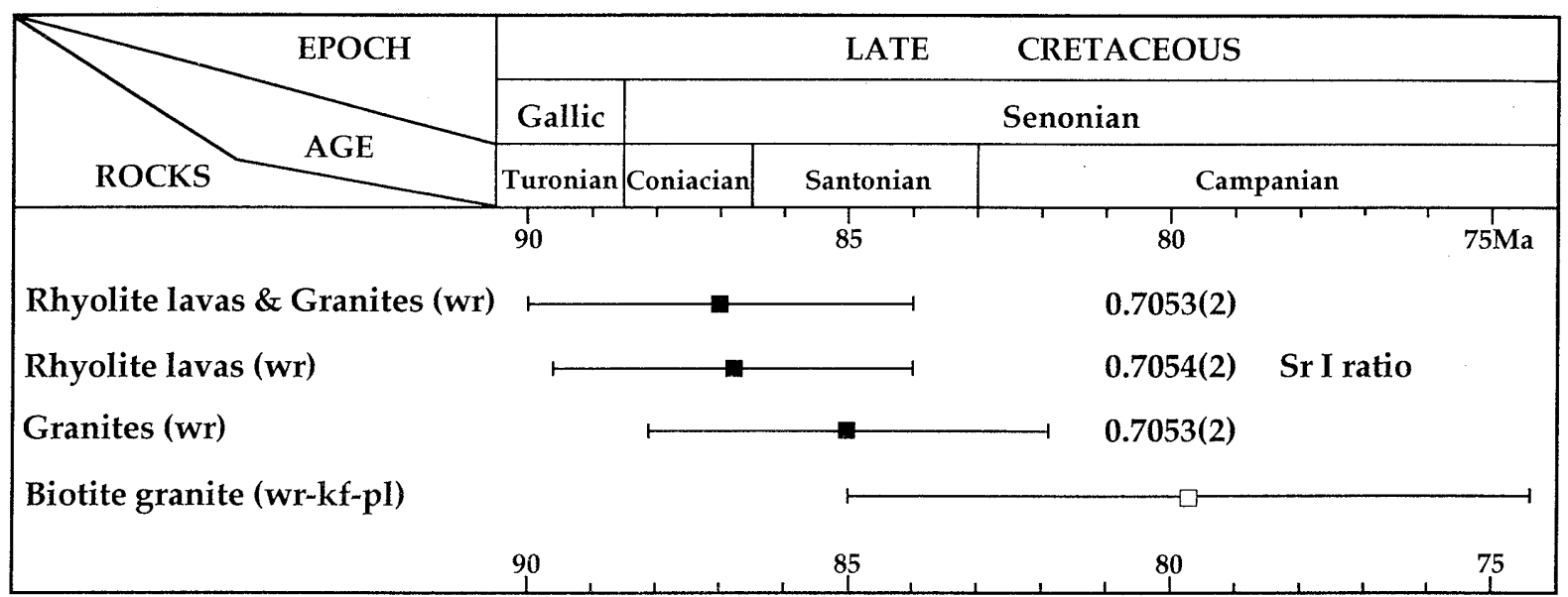

第 11 図. 流紋岩溶岩および花崗岩類の $\mathrm{Rb}-\mathrm{Sr}$ アイソクロン年代のまとめ.

Ma (Imaoka et al., 1993) と逆転している.

本地域の黒雲母花崗岩に対して河野・植田（1966）は93 $\mathrm{Ma}$ の黒雲母 K-Ar 年代を，さらにSeki (1978） は 92.9土 4.4 Ma の $\mathrm{Rb}-\mathrm{Sr}$ 全岩-黒雲母-カリ長石-斜長石アイソクロ ン年代を報告している．また，柴田・神谷（1974）は黒雲母 花崗岩中のペグマタイトの白雲母について $80.9 \pm 2.6 \mathrm{Ma}$ の $\mathrm{K}-\mathrm{Ar}$ 年代を報告している. 本研究で得られた $79.7 \pm 5.3 \mathrm{Ma}$ の全岩-カリ長石-斜長石アイソクロン年代は, 河野・植田 （1966）やSeki（1978）と比較すると䛊差範囲を越えてより 若い年代を示すが，柴田・神谷（1974）のデータとは䛊差範 囲で一致する．宇久鉱山の熱水変質岩中の白雲母 $\mathrm{K}-\mathrm{Ar}$ 年

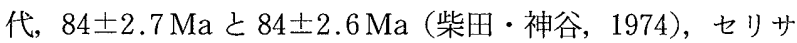
イト $\mathrm{K}-\mathrm{Ar}$ 年代 $87.1 \pm 2.6 \mathrm{Ma}$ (Kitagawa et al., 1988) は本 報告の花崗岩類の全岩アイソクロン年代と誤差範囲で一致す る.このことは鉣床の形成が花崗岩の貫入・定置とほぼ同時 に行われた結果と解釈される．野外における流紋岩溶岩と花 崗岩類の貫入関係と本研究のアイソクロン年代が整合的であ ること, 全岩アイソクロン年代と全岩鉱物アイソクロン年代 が誤差範囲で一致すること, さらに火山岩と深成岩の全岩化 学組成（第 $4 \sim 6$ 図）, SrI 值（第 2 表）および後述する $\varepsilon \mathrm{Sr}-$ $\varepsilon N d$ (第 12 図) の一致から考えて本研究で得られた花崗岩の アイソクロン年代は信頼できるあのといえる.

\section{2. 阿武層群の流紋岩溶岩と花崗岩類の成因的関係に ついて}

阿武層群福賀累層の流紋岩溶岩とそれを貫く花崗岩類の主 成分および微量元素成分について検討した結果，いずれにつ いても明瞭な違いは認めにくく，分化に伴いほぼ同一の組成 変化を示すことが分かった。この事実は両者が同じ化学組成 のマグマから形成されたことを示す。しかし，花崗岩類は流 紋岩溶岩に比較し，同じ分化指数の岩石の比較において Ba 含有量が低い.さらに，八ーカ一図（第 3,4 図）上で花崗岩 にみられるトレンドや Ba-Sr, Rb-Sr 図（第 5 図）は花崗岩 の分化を示し，それはマグマ溜まりにおいてカリ長石，斜長 石およびジルコンの分別結晶作用が起こったことを示してい る.
第 11 図は今回得られた流紋岩溶岩と花崗岩の $\mathrm{Rb}-\mathrm{Sr}$ 年代 をまとめたすのである.今回得られた $\mathrm{Rb}-\mathrm{Sr}$ 年代は, 流紋岩 溶岩の全岩年代が $86.8 \mathrm{Ma}$ ，花崗岩類の全岩年代が 85.0

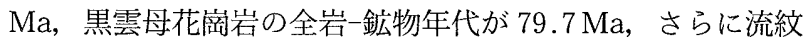
岩溶岩・花崗岩の全岩年代が $87.0 \mathrm{Ma}$ である.すべての全岩 年代は誤差範囲で一致し，さらに花岡岩の全岩年代と全岩鉱物年代屯誤差範囲で一致している．また，流紋岩溶岩の SrI 值は $0.70544 \pm 0.00024(2 \sigma)$, 花崗岩の SrI 值は 0.70526 $\pm 0.00023(2 \sigma)$ 之誤差範囲で一致している. 火山岩と深成岩 の SrI 值が誤差範囲で一致していることは興味深い。また， 第 12 図に $\varepsilon \mathrm{Sr}$ 初生値之 $\varepsilon \mathrm{Nd}$ 初生值の関係を示す。この図に は Terakado and Nakamura（1984）による中国地方に分布 する白亜紀火砕岩類のデー夕も同時にプロットした。本地域 の流紋岩溶岩および花岡岩類は全地球（Bulk Earth）よりや や enrichした組成を示し, $\varepsilon \mathrm{Nd}$ の変化幅が小さく同じ領域 にまとまってプロットされる。このことは火山岩と深成岩が 同じ起源物質（招そらく下部地殼）に由来していることを示 唆している. また, Terakado and Nakamura（1984）の白 亜紀火砕岩類のデー夕と比較すると，より枯渴した起源物質 に由来していることを示唆している。

以上の結果をもとに本地域の火山-深成作用について考察 する．阿武地域の流紋岩溶岩之花崗岩類は，野外で密接に 伴って産出し, 全岩の主成分および $\mathrm{Ba}$ を除く微量元素成分, $\mathrm{Rb}-\mathrm{Sr}$ 全岩年代, $\mathrm{SrI}$ 值や $\varepsilon \mathrm{Nd}$ 初生值が一致することから両 者は同じマグマ溜まりに由来すると考えられる．流紋岩溶岩 と花崗岩類の示す全岩アイソクロン年代 $87.0 \mathrm{Ma}$ はそれら を供給したマグマ溜まりが $\mathrm{Rb}-\mathrm{Sr}$ 系に関して閉鎖系となっ た年代，すなわちマグマ溜まりの形成年代と解釈できる. $\mathrm{Rb}-\mathrm{Sr}$ 全岩系の閉鎖温度については Stern et al.（1975）や Stern and Wyllie (1981) などの溶融実験のデータから 700 土50 ${ }^{\circ} \mathrm{C}$ 考えられる。ママグマ溜まりの形成年代とほほ時期を 同じにして流紋岩溶岩が $86.8 \mathrm{Ma}$ に噴出した。 また，一般に 花崗岩の全岩アイソクロンが示す年代は岩体の貫入年代と考 えられる.したがって本研究で得られた $85.0 \mathrm{Ma}$ という花崗 岩の全岩年代屯花崗岩体の貫入年代と考えられる。これらの 


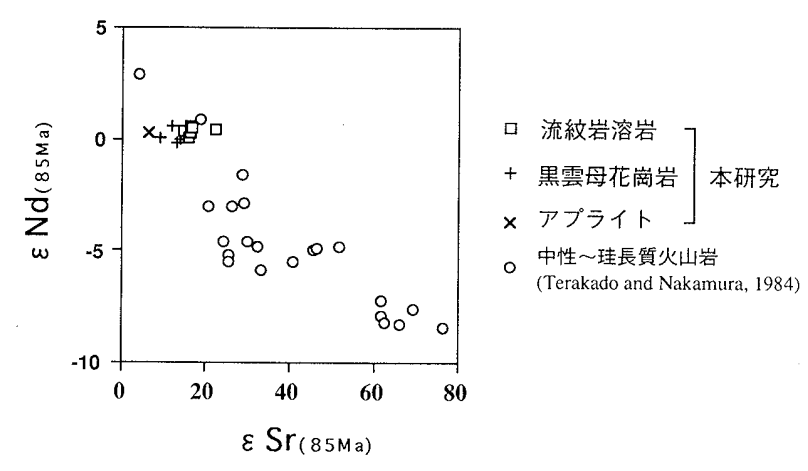

第 12 図. 阿武層群流紋岩溶岩および花崗岩類の $\varepsilon \mathrm{Sr}$ 初生 值と $\varepsilon \mathrm{Nd}$ 初生值の関係.

火成岩類を供給したマグマ溜まりでは, 斜長石, カリ長石, ジルコンの分別結晶作用が行われたが, 流紋岩が噴出後, 花 崗岩からアプライトが形成される段階においてはとくにカり 長石の分別が顕著に行われたすの上推定される.

以上のことより阿武地域に分布する福賀累層の流紋岩溶岩 とそれを貫く花崗岩類は共通の $\mathrm{Sr}, \mathrm{Nd}$ 同位体初生值を屯つ 起源物質に由来する同じマグマ溜まりからの一連の火山一深 成作用によって形成されたすのであると考えられる。

\section{結 論}

1. 阿武層群福賀累層の流紋岩溶岩とそれを貫く花崗岩類 には主成分および Ba を除く微量元素成分いずれについてむ 明瞭な違いが認めにくく，分化に伴いほぼ同一の組成変化を 示す. さらに, 花崗岩類にみられる $\mathrm{Ba}$ のトレンドはカリ長 石の分別の影響によるものと考えられる.

2. 流紋岩溶岩および花崗岩類について，以下の $\mathrm{Rb}-\mathrm{Sr}$ 年代と $\mathrm{Sr}$ 同位体初生値を得た。

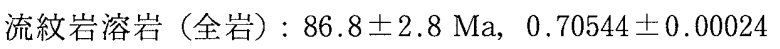
(MSWD 0.07)

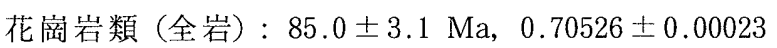
(MSWD 0.23)

黑雲母花崗岩（全岩-鉱物）: 79.7士5.3 Ma, $0.70521 \pm$ 0.00017 (MSWD 0.58)

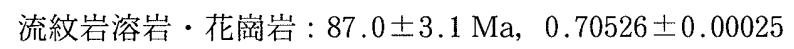
(MSWD 0.35)

流紋岩溶岩之花崗岩の $\mathrm{Rb}-\mathrm{Sr}$ 年代および $\mathrm{Sr}$ 同位体初生值 はすべて誤差範囲で一致している，これらの年代は地質関係 々矛盾せず，阿武地域において信頼できるはじめての Rb-Sr アイソクロン年代といえる.

3. 福賀累層の流紋岩溶岩と花崗岩類は $\varepsilon \mathrm{Sr}-\varepsilon \mathrm{Nd}$ 図上で 同じ領域にプロットされること, 全岩の主成分および微量成 分が類似することから阿武地域の火成岩類は共通の $\mathrm{Sr}, \mathrm{Nd}$ 同位体比をむつ起源物質に由来し，同じマグマ溜まりから一 連の火山一深成作用によって形成されたものと考えられる.

\section{謝辞}

島根大学総合理工学部の赤坂千秋さんには微量元素の抽出 に関してご指導いただくとともに有益な助言をいただいた。
蛍光 $\mathrm{X}$ 線分析装置の使用にあたっては山口大学機器分析セ ンタ一の永尾隆志助教授, 森福洋二技官に使用の便宜を図っ ていただいた。 また, 本研究の費用の一部に文部省科学研究 費補助金を使用した，以上の方々および関係当局に厚くお礼 を申し上げます。

\section{文献}

荒牧重雄・横山 泉, 1979, 火山の深部構造と浅部構造, マグマ溜ま り. 岩波講座地球科学, $7,157-172$.

地質調査所，1992，100 万分の 1 日本地質図 第 3 版.

Hanson, G. N., 1978, The application of the trace elements to the petrogenesis of igneous rocks of granitic composition. Earth Planet. Sci. Lett., 38, 26-43.

Hurford, A.J., 1990, Standardization of fission track dating calibration : Recommendation by the Fission Track Working Group of the I.U.G.S. Subcommission on Geochronology. Chem. Geol., 80, 171-178.

飯泉 滋, 1996, 表面電離型質量分析計, MAT 262 に上る岩石・鉱 物試料の $\mathrm{Sr}, \mathrm{Nd}$ 同位体組成の測定. 島根大地球資源環境学研 報, no. 15, 153-159.

Iizumi, S., Maehara, K., Morris, P. A. and Sawada, Y., 1994, Sr isotope data of some GSJ rock reference samples. Mem. Fac. Sci. Shimane Univ., 28, 83-86.

lizumi, S., Morris, P. A. and Sawada, Y., 1995, Nd isotope data for GSJ reference samples JB- 1 a, JB- 3 and JG- 1 a and the La Jolla standard. Mem. Fac. Sci. Shimane Univ., 29, 73-76.

Imaoka, T., Nakajima, T. and Itaya, T., 1993, K-Ar ages of hornblendes in andesite and dacite from the Cretaceous Kanmon Group, Southwest Japan. Jour. Mineral. Petrol. Econ. Geol., 88, 265-271.

Imaoka, T . and Nakashima, K., 1983, Temporal and spatial variations of magnetic susceptibility of Cretaceous to Neogene igneous rocks from the central and western Chugoku Province, Japan. Jour. Sci. Hiroshima Univ., Ser. C, 8, 1-30.

今岡照喜 - 大平 武 - 沢田順弘 - 板谷徹丸, 1994, 中国 - 四国地方に 扣ける白亜紀～第三紀火成岩類の放射年代. 岡山理科大自然科 学研報, no. 20, 3-57.

今岡照喜 ·上田 董・村上允英 - 鈴木哲夫 - 脇坂安彦 - 甲斐野信 一・横山義人・佐々木浩, 1984, 山口県十種ヶ峰周辺の白亜紀阿 武層群。山口大教養部紀要, 18, 79-101.

IUGS Subcommission, 1973, Plutonic rocks, classification and nomenclature recommended by the IUGS Subcommission on the systematics of igneous rocks. Geotimes, 18, 26-30.

岩生周一, 1950, 山口県宇田郷名振鉱山の蠟石鉱床について. 地調月 報, $1 ， 1-7$.

角縁 進 - 永尾隆志 - 今岡照喜 - 松本征夫 - 白木敬一, 1989, 监光 X 線分析装置による岩石中の微量元素の定量. 山口大教養紀要, $23,43-54$.

神谷雅晴, $1974 \mathrm{a}$, 山口県宇久万う石鉱山の熱水変質作用. 鉱山地質, $24,31-43$.

神谷雅晴, $1974 \mathrm{~b}$, 山口県阿武地域白要系の層序および地質構造一阿 武地区ろう石鉣床の研究 その 1一. 地調月報, 25， 105-118.

Kamitani, M., 1977, Genesis of the andalusite-bearing Roseki ore deposits in the Abu district, Yamaguchi Prefecture, Japan. Rept. Geol. Surv. Japan, 28, 201-264.

河野義礼・植田良夫, 1966 , 本邦火成岩の K-Ar dating (V) 一西南 日本の花崗岩類一. 岩鉱, 56, 191-206.

Kitagawa, R., Nishido, H. and Takeno, S., 1988, K-Ar ages of pyrophyllite ("Roseki") deposits in the Chugoku district, Southwest Japan. Mining Geol., 38, 357-366.

村上允英，1968，地質図「須佐」龱幅，山口県地質図（5万分の 1 ).

Murakami, N., 1974, Some problems concerning late Mesozoic to early Tertiary igneous activity on the inner side of Southwest Japan. Pacific Geol., no. 8, 139-151.

村上允英, 1985 , 中国地方西部における中生代後期 古第三紀火成活 動史. 地質雑, 91, 723-742. 
村上允英・今岡照喜，1986 編，「西中国および周辺地域の酸性〜中性 火成活動」. 山口大教養部紀要, 村上允英教授記念号, $419 \mathrm{pp}$.

西村祐二郎・今岡照喜 - 宇多村 譲・亀谷 敦, 1995, 新編山口県地 質図 $(1: 150,000)$. 山口地学会.

Seki, T., 1978, Rb-Sr geochronology and petrogenesis of the Late Mesozoic igneous rocks in the Inner Zone of the southwestern part of Japan. Mem. Fac Sci. Kyoto Univ, 45, 71-110.

柴田 賢・神谷雅晴, 1974, 山四県阿武地区ろう石鉱床の $\mathrm{K}-\mathrm{Ar}$ 年代 一阿武地区ろう石鉱床の研究 その 2 -。地調月報, 25, 323330.

Steiger, R.H. and Jäger, E., 1977, Subcommision on geochronology, convention on the use of decay constants in geo-and cosmo-chronology. Earth Planet. Sci. Lett., 36, 359-362.

Stern. C.R. and Wyllie, P.J., 1981, Phase relations of I-type granite with $\mathrm{H}_{2} \mathrm{O}$ to 35 kilobars : the Dinkey Lakes biotite-granite from Sierra Nevada batholith. Jour. Geophys. Res., 86, 10412-
10422.

Stern. C. R., Wuu-/Liang and Wyllie, P.J., 1975, Basalt-andesiterhyolite- $\mathrm{H}_{2} \mathrm{O}$ : Crystallization interval with excess $\mathrm{H}_{2} \mathrm{O}$ and $\mathrm{H}_{2} \mathrm{O}$-undersaturated liquidus surfaces to 35 kilobars, with implication for magma genesis. Earth Planet. Sci. Lett., 28, 189-196.

高橋正樹, 1990, マグマ溜まり : 形態・構造・進化. 火山, 34, S 83S 98.

Terakado, Y. and Nakamura, N., 1984, Nd and Sr isotopic variations in acidic rocks from Japan : significance of uppermantle heterogeneity. Contrib. Mineral. Petrol., 87, 407-417.

上田 薫・西村 進，1982，阿川-湯本および青海島地域に分布する 白亜紀後期火山岩類の層序とフィッション, トラック年代. 日本 地質学会第 89 年学術大会講演要旨, 382 .

York, D., 1966, Least-squares fitting of a straight line. Can. Jour. Phys., 44, 1079-1086.

（要 旨）

弓削智子・今岡照喜・飯泉 滋，1998，山口県阿武地域における白亜紀流紋岩類と花崗岩類の全岩 化学組成および Sr, Nd 同位体比. 地質雑, 104, 159-170. (Yuge, T., Imaoka, T. and Iizumi, S., 1998, Whole-rock chemistry and $\mathrm{Sr}$ and $\mathrm{Nd}$ isotope ratios of Cretaceous rhyolites and granitoids in Abu district, Yamaguchi Prefecture, Southwest Japan. Jour. Geol. Soc. Japan, 104, 159-170.)

山口県阿武地域に分布する白亜紀阿武層群の流紋岩とそれを貫く花崗岩類の成因的関係につい て検討した，両者には全岩化学組成（Ba を除く）について顕著な差異は認められない，流紋岩

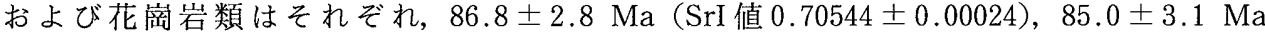
(0.70526士0.00023) の $\mathrm{Rb}-\mathrm{Sr}$ 全岩年代と $\mathrm{Sr}$ 同位体初生值を示す.それらの全試料からは, $87.0 \pm 3.1 \mathrm{Ma}(0.70526 \pm 0.00025)$ のアイソクロンが求められた。一方, 花崗岩の全岩一鉱物ア イソクロン年代は $79.7 \pm 5.3 \mathrm{Ma}(0.70521 \pm 0.00017)$ を示す。両者の産状，全岩組成， $\mathrm{Sr}, \mathrm{Nd}$ 同位体比のデー夕から，阿武地域の流紋岩と花崗岩類は，共通の $\mathrm{Sr}, \mathrm{Nd}$ 同位体比をもつ起源物 質に由来し，同じマグマ溜まりから一連の火山-深成作用によって形成されたものと考えられる. 